\title{
RENT-A-JUDGES AND THE COST OF SELLING JUSTICE
}

\author{
ANNE S. KIM
}

\section{INTRODUCTION}

For many free-market enthusiasts, it is axiomatic that whatever government can do, businesses can do better. Especially during the 1980s, "privatization" was the watchword for those frustrated by the supposed high cost and inefficiency of governmentprovided services. ${ }^{1}$ Many states have, in fact, turned to the private sector to provide such essential public services as garbage pickup ${ }^{2}$ and prisons. ${ }^{3}$ In California, even the state courts have succumbed to privatization.

Private judging-or "rent-a-judging"-has expanded over the past decade in California into a multimillion-dollar industry. ${ }^{4} \mathrm{Un}$ like arbitrators or mediators, rent-a-judges are officially part of the state court system, and their judgments have the same effect as judgments of any other state court. Superficially, a rent-a-judge differs from his public court colleagues in only one respect: the source of his paycheck. ${ }^{5}$

1. For a sampling of recent, enthusiastic analyses of the virtues of privatization, see ENTRePreneurship AND the Privatizing of Government (Calvin A. Kent ed., 1987); Randall Fitzgerald, When Government Goes Private (1988); Report of the President's Commission on Privatization, Privatization: Toward More EfFec. TIVE GOVERNMENT (1988).

2. Calvin A. Kent \& Sandra P. Wooten, Privatization: The Entrepreneurial Response, in ENTREPRENEURSHIP AND THE PRIVATIZING OF GOVERNMENT, supra note 1, at 145, 152.

3. Id. at 154-55; Robert P. Weiss, Private Prisons and the State, in PRIVATIZING CRIMINAL JUSTICE 24, 30-31 (Roger Matthews ed., 1989).

4. At least three companies provide rent-a-judge services in California: Judicial Arbitration \& Mediation Services Inc. (JAMS), based in Orange; the Philadelphia-based Judicate, which has offices in California; and the San Francisco-based Judicial Resources Inc. Mark Thompson, Rented Justice, CAL. LAW., March 1988, at 42, 43. Gross revenues for JAMS, the biggest of these companies, had been projected to reach approximately $\$ 24$ million in 1991-1992 (including fees from arbitration and mediation as well as rent-ajudge services). Jean Guccione, Selling Justice, CAL. LAw., Oct. 1991, at 32, 36.

5. Details about the rent-a-judge system are discussed infra Part I. 
From its beginning, rent-a-judging has prompted worries about the propriety of privatized justice. Despite its touted efficiency, the rent-a-judge system is marred by constitutional and policy concerns. Opponents have especially decried the creation of a twotiered system of justice-one for the wealthy and one for the poor. Rent-a-judge justice, though speedy, is also quite expensive. The most popular, and presumably the best, rent-a-judges command $\$ 5,000$ a day. ${ }^{6}$ Consequently, only the wealthiest litigants can afford a rent-a-judge-a result that is not only inequitable but quite possibly unconstitutional under California law. ${ }^{7}$

The rent-a-judge system also has raised a number of practical considerations. Critics have condemned the secrecy of rent-a-judge proceedings and the lack of disclosure requirements or other regulations to govern the behavior of rent-a-judges and ensure their impartiality. ${ }^{8}$ Moreover, the California courts have yet to unravel the numerous procedural implications of rent-a-judge practice. For example, the preclusive effect of a rent-a-judge's judgment still is untested, as is its authority as precedent. ${ }^{9}$ Also unclear is the scope of a rent-a-judge's powers. Despite some limitations, rent-ajudges appear to have broad powers, and the line between private and public judges seems fuzzy at best. Particularly disturbing is the apparent power of rent-a-judges to call juries. ${ }^{10}$

6. See infra note 72 and accompanying text.

7. For a discussion of the constitutional argument, see infra Part II.

8. In February 1993, in response to some of these criticisms, the Judicial Council of California approved a set of rules to govern cases tried by privately compensated judges. CAL. R. CT. 244(d) (regulating use of public facilities by temporary judges); CAL. R. CT. 532.1(c) (regulating use of public facilities by general referees). These rules were the first attempt to regulate rent-a-judges, and their approval came after nearly four years of debate. Tom Dresslar, Rules on Private Judging Guard Access, Disclosure, LOS ANGELES DAILY J., Mar. 5, 1993, at A5. Although the new rules may placate some critics, they do nothing to address many serious policy issues. Details and policy implications are discussed infra Part III.

9. See infra text accompanying note 186.

10. See infra notes 38-46 and accompanying text. All these concerns are also becoming more urgent as more states adopt the use of private judges. In 1992, the rent-a-judge system expanded to New York, where JAMS and Endispute, two alternative dispute resolution (ADR) service companies, opened offices on Park Avenue. Marcia Chambers, $A$ Private System Has Energed That Will See Cases Drawn Into an Unseen World, NAT'L L.J., June 15, 1992, at 15. For an analysis of the New York statute authorizing private judging, see David J. Shapiro, Note, Private Judging in the State of New York: A Critical Introduction, 23 COLUM. J.L. \& SOC. PROBS. 275 (1990). Ten other states also have statutes that permit proceedings similar to the rent-a-judge proceedings authorized in California. See Kan. Stat. ANN. \& 60-253 (1983); ME. REV. STAT. ANN. tit. 14, § 1151 
This Note expands on all these concerns and concludes that the rent-a-judge system is both undesirable as a matter of public policy and unconstitutional under California law. Part I surveys the history and statutory bases of the rent-a-judge system and examines its practice in California today. This Part also considers the business aspects of private judging. Part II details the argument that the rent-a-judge system violates the due process and equal protection clauses of the California Constitution. Finally, Part III analyzes the policy debate over private judging. Specifically, this Part addresses the larger question of whether privatized justice is desirable as a matter of public policy. Concededly, what can be called private justice already exists in the guises of arbitration and mediation. Arbitration and mediation, however, are wholly private forms of dispute resolution, and this Note argues that the rent-a-judge system is an intolerable fusion of the public and private sectors. Rent-a-judges have broad authority to marshal the power of the state, which raises troubling questions about the extent to which private parties should be able to co-opt such authority.

\section{General Background, History, AND Current Practice}

\section{A. Statutory Procedures}

California law authorizes two types of private trials: trials conducted by a temporary judge ${ }^{11}$ and trials conducted by a referee. ${ }^{12}$ Both temporary judges and referees may serve as rent-ajudges. Temporary judges differ from referees in the scope of their powers and in their qualifications. In general, temporary judges are closer to the "real thing" than are referees. Both proceedings, however, require the consent of all parties, and the parties are free to choose their judge.

(West 1964); Mo. ANN. STAT. §§ 515.010-.230 (Vernon 1949); NEB. REv. STAT. $\S \S$ 25-1129 to -1137 (1989); N.H. REV. STAT. ANN. § 519:9 (1974); N.C. R. CIV. P. 53; OKLA. STAT. ANN. tit. 12, $\$ 612-615$ (West 1988); S.C. R. CIV. P. 53; TEX. CIV. PraC. \& REM. CODE ANN. \$§ 151.001-.013 (West 1994); WASH. REV. CODE ANN. §§ 4.48.010-130 (West 1988). All of these statutes date from the late 1800s, except for the Texas statute, which was enacted in 1987. For an analysis of private judging in Texas, see W. Frank Newton \& David G. Swenson, Adjudication by Privately Comipensated Judges in Texas, 36 BAYLOR L. REV. 813 (1984).

11. CAL. CONST. art. VI, § 21.

12. Cal. Civ. Proc. Code $\S \S 638-645$ (West 1993 \& Supp. 1994). 
1. Appointment of a Rent-a-Judge and Procedures for Trial. As noted, rent-a-judges come in two varieties: teinporary judges and referees. The California Constitution authorizes the appointment of temporary judges. Under article VI, section 21, "[o]n stipulation of the parties litigant the court may order a cause to be tried by a temporary judge who is a member of the State Bar, sworn and einpowered to act until final determination of the cause."13 Although private parties can choose to use a temporary judge for a private trial, most temporary judges now in service have been appointed and paid for by the state to help take up the slack in regular state courts. In fiscal 1987-1988, temporary judges served more than 3,100 days in the California superior courts. ${ }^{14}$

Most privately paid judges are instead referees, who are authorized to serve under California's reference statutes. California law authorizes two types of reference proceedings: "special" references and "general" references. ${ }^{15}$ Rent-a-judges perform the latter. Special references are usually ordered by the court, and the consent of the parties is not required. ${ }^{16}$ In these proceedings, the referee decides specific questions of fact and reports his findings to the trial judge. ${ }^{17}$ The special referee's findings are advisory and are not binding as judgments in and of themselves. ${ }^{18}$ On the other hand, in a general reference, which rent-a-judge proceedings almost always are, all parties must consent, ${ }^{19}$ and the chosen referee decides all issues of fact and law. ${ }^{20}$ Moreover, the referee's decision stands as the judgment of the court. ${ }^{21}$ The primary stat-

13. Cal. Const. art. VI, § 21.

14. 2 Judicial Council of California, 1989 Administrative Office Report 146 (1989) (Table T-71).

15. CAL. Crv. Proc. Code §§ 638-645 (West 1993 \& Supp. 1994).

16. Id. § 639 .

17. Id. $\S \S 639,643$.

18. Ellsworth v. Ellsworth, 269 P.2d 3, 5 (Cal. 1954) (en banc).

19. CAL. Civ. PROC. CODE \& 638; see Holt v. Kelly, 574 P.2d 441, 442 (Cal. 1978) (en banc).

20. Cal. Civ. Proc. Code § 638.

21. The California statute provides that

[t]he decision of the referee or commissioner upon the whole issue must stand as the decision of the court, and upon filing of the statement of decision with the clerk of the court, or with the judge where there is no clerk, judgment may be entered thereon in the same manner as if the action had been tried by the court.

Id. $\S 644$. 
ute authorizing general reference proceedings is section 638 of the California Code of Civil Procedure. ${ }^{22}$ This statute does not contain provisions requiring referees to meet specific qualifications, ${ }^{23}$ and unlike temporary judges, referees presumably do not even need to be lawyers. ${ }^{24}$

Once the parties have chosen a judge, they request the trial court to issue an order of reference or an order of appointment (in the case of a temporary judge) authorizing the rent-a-judge to hear the case. This order may also contain stipulations delineating the scope of the rent-a-judge's authority. For example, the litigants can agree to change or abandon formal rules of pleading, evidence, or procedure. ${ }^{25}$ Otherwise, the usual court rules apply. ${ }^{26}$ The agreement may also contain provisions concerning payment of the rent-a-judge. Parties usually split the costs evenly. ${ }^{27}$ Once the court issues its order of reference or its order appointing a temporary judge, the parties are free to determine when and where the trial will take place; California statutes impose no restrictions on these details. ${ }^{28}$

After the trial, if the rent-a-judge was a temporary judge, judgment is entered with the court just as if an active judge has been presiding. If the trial was a general reference, the rent-ajudge referee must file a statement of decision with the court within twenty days. ${ }^{29}$ In either case, the rent-a-judge's reports must contain both findings of fact and conclusions of law. ${ }^{30} \mathrm{Be}-$ cause their judgments are equivalent to the judgments of any state

22. The statute provides as follows:

A reference may be ordered upon the agreement of the parties filed with the clerk, or judge, or entered in the minutes or in the docket:

1. To try any or all of the issues in an action or proceeding, whether of fact or of law, and to report a statement of decision thereon;

2. To ascertain a fact necessary to enable the court to determine an action or Id. $\S 638$. proceeding.

23. See id. $\S \S 638-645$.

24. Litigants invariably choose retired state judges, however, because they want a competent legal determination of their case. Barlow F. Christensen, Privdte Justice: California's General Reference Procedure, 1982 AM. B. FouND. RES. J. 79, 81.

25. Richard Chernick, The Rent-a-Judge Option, LOS ANGELES LAw., Oct. 1989, at $18,20$.

26. Id.

27. Christensen, supra note 24 , at 82 .

28. See CAL. CIV. Proc. CODE $\$ \S 638-645$.

29. Id. § 643; see In re Marriage of Demblewski, 31 Cal. Rptr. 2d 533, 535 (1994).

30. Cal. Civ. Proc. Code § 643. 
court $^{31}$-and therefore are appealable-rent-a-judges must follow substantive law in making their decisions. The right of appeal is the primary difference between rent-a-judges and arbitrators or mediators. ${ }^{32}$ By reserving the right to appeal, the rent-a-judge system therefore provides parties the speed of arbitration without the risks. ${ }^{33}$

2. The Powers of a Rent-a-Judge. The full extent of a renta-judge's powers are not clear, although numerous cases hold that private judges have the power to conduct trials the same way public judges do. ${ }^{34} \mathrm{~A}$ rent-a-judge's powers depend on whether he was appointed as a temporary judge or as a referee. Temporary judges indisputably enjoy more authority than do referees. With a few major limitations, temporary judges wield the same panoply of powers as active judges. Most significantly, temporary

31. Id. \& 644.

32. Under California law, a court will not vacate an arbitration award absent corruption, fraud, or prejudicial misconduct on the part of the arbitrator. CAL. CIV. PRoc. CODE $§ 1286.2$ (West Supp. 1994). The Federal Arbitration Act also has stringent standards on review. The text of the Federal Arbitration Act is substantially similar to the California statute and permits a court to vacate an arbitration award only upon a showing of corruption, fraud, impermissible partiality, or prejudicial misconduct. 9 U.S.C. \& 10 (Supp. IV 1992).

33. Few parties, however, seem to take advantage of their right to appeal. A search on Westlaw turned up only about half a dozen cases in which parties appealed rent-ajudge judgments. Search of Westlaw, CA-CS database (Sept. 24, 1994); see In re Marriage of Demblewski, 31 Cal. Rptr. 2d 533 (1994); Salka v. Dean Homes of Beverly Hills, Inc., 22 Cal. Rptr. 2d 902 (1993); Turner v. Architectural Design Group, 262 Cal. Rptr. 375 (Ct. App.), review denied, ordered not officially published (Nov. 30, 1989); Four Embarcadero Ctr. Venture v. Mr. Greenjeans Galleria Corp., 250 Cal. Rptr. 325 (Ct. App.), review denied, ordered not officially published (Oct. 27, 1988); North Coast Village, Ltd. v. Superior Court, 209 Cal. Rptr. 26 (Ct. App.), review denied, ordered not officially published (Mar. 28, 1985). The majority of these cases were denied review by the California Supreme Court, which, interestingly, ordered the appellate court decisions to be "depublished" and therefore not binding as precedent.

Private judge Lester Olson theorizes that few parties appeal because

[t] $]$ he same economic and pragmatic reasons that compel a decision to use the private procedure for the trial continue to exist. A speedy trial and resolution of the dispute is needed. Finality after the trial is still a very important consideration. Second, the judicial selection process, by which all parties must fully agree on the particular judge to try the case, guarantees a high degree of confidence in the judge selected for the case.

Lester E. Olson, Pick Your Own Judge: An Insider's Look at the California Rent-a-Judge System, COMPLEAT LAw., Winter 1987, at 38, 40.

34. See, e.g., Clark v. Rancho Santa Fe Ass'n, 265 Cal. Rptr. 41, 51 (1989); Ellsworth v. Ellsworth, 269 P.2d 3, 3 (Cal. 1954); In re Burns' Estate, 2 Cof. 39 (1888); Plant v. Fleming, $20 \mathrm{Cal}, 93$ (1862). 
judges can punish for contempt, ${ }^{35}$ although their contempt power may be imposed only upon stipulation by a "party litigant." contrast, referees cannot punish anyone for contempt. ${ }^{37}$ This is less of a handicap than it appears. Because the parties before a rent-a-judge have consented to this forum, it is unlikely that a rent-a-judge will have to coerce any party into doing anything.

All rent-a-judges also have the power to call in juries, which one commentator has condemned as "a form of involuntary servitude." 38 Defenders of "rent-a-juries," far as the jurors are concerned, "it's the same function no matter who is presiding." ${ }^{40}$ One article cites several instances in which litigants used rent-a-juries as well as rent-a-judges. ${ }^{41}$ According to this article, the jurors never knew they were taking part in private trials. ${ }^{42}$ One such trial took place in an empty room of the traffic court building, ${ }^{43}$ and the parties chose the jurors from the county court's jury pool. ${ }^{44}$ The public courts do not seem to mind this incursion imto their territory. Judges in the Los Angeles and Orange County superior courts apparently have agreed to provide

35. See Sarracino v. Superior Court, 529 P.2d 53, 60 (Cal. 1974).

36. Id.; see also In re Plotkin, 127 Cal. Rptr. 190, 192 (Ct. App. 1976); Nierenberg v. Superior Court, 130 Cal. Rptr. 847 (Ct. App. 1976). However, a temporary judge cannot compel a third-party witness to testify in court. See David B. Stern, Rent-a-Judge or Rent$a$-Wimp, LOS ANGELES LAW., Oct. 1991, at 40 .

37. Marcus v. Workmen's Compensation Appeals Bd., 111 Cal. Rptr. 101, 105 (Ct. App. 1973). This case held broadly that no "subordinate officer, court commissioner or referee" can hold someone in contempt. Id. at 104. This case seems to imply that a referee may cite someone for contempt but cannot enforce the contempt citation. Instead, enforcement must come from the court that ordered the reference. Id. at 103-04.

38. Mark Thompson, Why not Rent a Jury, Too?, CAL. LAw., Mar. 1988, at 45 (quoting Robert Gnaizda, an attorney with a public interest firm in San Francisco).

39. Id. Jurors in rent-a-judge proceedings are not actually "rented" but are called through the usual process for summoning juries. The term "rent-a-jury" is used to distinguish juries serving in rent-a-judge proceedings from those serving in regular public court proceedings.

40. Id. (quoting $\mathrm{H}$. Warren Knight of JAMS).

41. Id.

42. Id. The article quotes the judge who presided over one such trial, Charles Woodmansee: "So far as I'm aware, no one made a point of telling [the jurors what was going on]." Id.

43. Id.

44. Id. One detail the article does not make clear is whether the private judge in this case was a temporary judge or a referee. Temporary judges appointed and paid by the state to work in the regular courts have long presided over jury trials. Thus, it is not anomalous for a privately paid temporary judge to preside over a jury. No cases, however, have directly established the power of referees to use juries. 
both jury panels and vacant courtrooms. ${ }^{45}$ However, the Judicial Council of California has recently promulgated rules on rent-ajudge practice that attempt to limit these arrangements. One of these rules prevents the use of public courtrooms and resources for private trials without the consent of a presiding judge. ${ }^{46}$ This prohibition leaves open the possibility, however, that rent-a-judges can call juries through alternate means. There is also the possibility that presiding judges will simply rubber-stamp requests to use public courtrooms and to call jurors.

Another issue is when the power of a private judge ends. For temporary judges, the same rules that govern active judges apply. ${ }^{47}$ The temporary judge has the power to hear post-trial motions such as a motion for new trial or a motion to tax costs. ${ }^{48}$ Some commentators believe that the post-trial powers of referees may be more limited because their authority ends once they file their statement of decision with the court. ${ }^{49}$ The California Court of Appeal has held, however, that referees do have the power to hear a motion for new trial. ${ }^{50}$

\section{B. The History of Rent-a-Judges in California and a Look at Cur- rent Rent-a-Judge Practice}

The statutory authority for rent-a-judge proceedings has existed for decades. The California general reference statute dates back to $1872,{ }^{51}$ and the constitutional provision authorizing temporary judges was enacted in $1966 .{ }^{52}$ It was not until the late 1970 s, however, that rent-a-judges became popular. In 1976, three Los Angeles lawyers ${ }^{53}$ dreamed up the idea of using a general referee to handle a complex commercial case..$^{54}$ Then in $1979, \mathrm{H}$. Warren

45. Id.

46. CAL. R. CT. 244(d), 532(d) (regulating use of public facilities by temporary judges); $i d$. 244.1(c), 532.1(c) (regulating use of public facilities by general referees). These rules became effective July 1, 1993.

47. Chernick, supra note 25 , at 19.

48. Id.

49. Id. at $22-23$.

50. Clark v. Rancho Santa Fe Ass'n, 265 Cal. Rptr. 41, 52 (Ct. App. 1989).

51. CAL. CIv. Proc. CODE $\S 638$ historical note (West 1993).

52. CAL. CONST. art. VI, \& 21.

53. The lawyers were Hillel Chodos, James H. Craig, and Seth M. Hufstedler. See Christensen, supra note 24 , at 80.

54. Id. 
Knight, an Orange County Superior Court judge, retired from the bench to found Judicial Arbitration \& Mediation Services (JAMS), the first rent-a-judge company and now the nation's largest provider of alternative dispute resolution (ADR) services. ${ }^{55}$ Today, at least three companies provide rent-a-judges, ${ }^{56}$ and many more judges work on a free-lance basis. ${ }^{57}$

1. Rent-a-Judges' Customers. According to some sources, rent-a-judges are most popular in two types of cases: complex commercial litigation and divorces..$^{58}$ One source found that half of the cases referred to rent-a-judges in Los Angeles were divorces. ${ }^{59}$ Litigants in complex commercial disputes might prefer renta-judge proceedings for several reasons besides their speed. For example, parties may choose a private judge because of his specialized knowledge in a given area. ${ }^{60} \cdot \mathrm{A}$ primary advantage of using rent-a-judges in family disputes is the relative privacy of the proceedings. ${ }^{61}$ Because litigants generally split the costs, rent-ajudges rarely hear cases involving impecunious plaintiffs and corporate defendants.

Private parties are not the only ones opting for rent-a-judges, however. Some state agencies also are taking their litigation private. For example, the University of California at San Francisco agreed to use a rent-a-judge in settling a dispute with a neighbor-

55. Nicholas Varchaver, Dispute Revolution, AM. LAw., Apr. 1992, at 60, 62. This article provides a good comprehensive history of JAMS.

56. See supra note 4.

57. In Los Angeles County alone, more than 60 retired judges hire themselves out on a free-lance basis. Olson, supra note 33, at 39. The 1994 Directory of California Lawyers lists 393 retired judges available for private dispute resolution.

58. Gail D. Cox, The Best Judges Money Can Buy, NAT'L L.J., Dec. 21, 1987, at 1, 23; Olson, supra note 33, at 39. Cox quotes rent-a-judge Jerry Pacht as saying that entertainment law disputes are also good candidates for rent-a-judging. Cox, supra, at 23. For example, Pacht handled a case involving a dispute over the cassette distribution rights of the movie Rambo. Id.

59. Cox, supra note 58, at 23. Celebrities who have resorted to rent-a-judges for their divorce proceedings include sportscar maker John DeLorean and talk-show host Johnny Carson. FitzGERALD, supra note 1, at 97.

60. Thompson, supra note 4, at 44-45. John J. Welsh, general counsel of JAMS, notes that many judges have built reputations as specialists in areas such as construction disputes. Telephone Interview with John J. Welsh, General Counsel, JAMS (Oct. 15, 1993).

61. Although rent-a-judge proceedings are nominally open to the public, see infra text accompanying notes 202-07, they do not tend to be held in courthouses or in public buildings and are thus far less accessible to the public. Chernick, supra note 25 , at 18. 
hood association that wanted to stop construction of a new pharmacy school. ${ }^{62}$ In another case, the State Air Resources Board turned to a private judge to settle a pollution dispute with a private oil and gas company. ${ }^{63}$ State agencies' reliance on rent-ajudges troubles those who believe that private judges should not be deciding matters of public policy. ${ }^{64}$

2. The Rent-a-Judge Business. Rent-a-judge practice is big business. Over the past decade, the number of retired judges for hire has increased exponentially. JAMS, for example, started out in 1979 with a single retired judge. ${ }^{65}$ In 1993, JAMS had 230 retired judges working out of fourteen offices in three states. ${ }^{66}$ JAMS judges handle about 13,000 cases a year. ${ }^{67}$ Most of these involve arbitration and mediation, but a fair number, especially in Orange County, involve referee proceedings. ${ }^{68}$

Revenues for JAMS and other ADR companies have grown as quickly as the number of judges for hire. In fiscal 1987-1988, gross annual revenues for JAMS totaled about $\$ 2.7$ million. ${ }^{69}$ In fiscal 1991-1992, revenues had been expected to reach $\$ 24$ million. ${ }^{70}$ A rival company, Judicate, has boasted a similar increase im profits: gross annual revenues climbed from $\$ 1.8$ million in fiscal 1990 to a projected $\$ 6.5$ million in $1991 .^{71}$ Rent-a-judges generally cost between $\$ 300$ to $\$ 500$ an hour, though some popular judges command per diem fees of up to $\$ 5,000 .^{72}$ Although JAMS officials interviewed declined to disclose the average earnings of a JAMS judge, General Counsel John Welsh acknowledged

62. Steven Pressman, Public Issues and Private Judges, CAL. LAw., Nov. 1990, at 17 (citing Laurel Heights Improvement Ass'n v. Regents of the Univ. of Cal., S.F. Super. Ct. No. 862850 (1989) (unpublished disposition)).

63. Cox, supra note 58, at 24. The state lost in the rent-a-judge trial but later won in the California Supreme Court. Western Oil \& Gas v. State Air Resources Bd., 691 P.2d 606 (Cal. 1984).

64. For further discussion, see infra Part III.

65. Guccione, supra note 4 , at 32 .

66. Telephone Interview with John J. Welsh, General Counsel, JAMS, supra note 60.

67. Id.

68. See infra text accompanying notes $94-96$.

69. Guccione, supra note 4 , at 36 .

70. Id.

71. Id.

72. Telephone Interview with John J. Welsh, General Counsel, JAMS, supra note 60. Welsh stated that these figures apply not only to JAMS judges, but also to free-lance judges and judges from other ADR companies. Id. 
that the typical retired judge can earn far more as a rent-a-judge than he earned while on the bench. One source speculates that JAMS judges typically work sixty to seventy hours a month and take home about $\$ 120,000$ a year. ${ }^{73}$ In contrast, in 1992, full-time judges on the California Superior Courts earned $\$ 99,297$ a year. ${ }^{74}$ In addition, retired judges older than sixty who served twenty years on the bench receive pensions equaling $75 \%$ of their fulltime salaries. ${ }^{75}$ State retirement benefits also include health insurance. ${ }^{76}$

One of the early fears of critics was that the rent-a-judge practice would cause a "brain drain." L77 Lured by big profits, judges presumably would leave the bench in droves. However, several sources indicate that massive early retirements have not occurred, perhaps because state judges must stay on the bench for twenty years to qualify for maximum retirement benefits. ${ }^{78}$ One recent survey of retired judges found that money-making opportunities as rent-a-judges or as arbitrators and mediators ranked below other reasons for retiring, such as "desire for rest and relaxation, and dissatisfaction with service in the public justice system." Money is definitely on the mind of many retirees, however. In the same survey, $35 \%$ of retirees listed opportunities in ADR as one of the top three reasons for leaving the bench. ${ }^{80}$ When Judge Lester E. Olson retired from the bench several years ago, the announcement for his retirement party, reprinted in California Lawyer, depicted the judge skiing down a slope and making a giant dollar sign in the snow. ${ }^{81}$ The announcement read:

73. Varchaver, supra note 55 , at 63.

74. Id.

75. Id.

76. Id.

77. JUDICIAL COUNCIL OF CALIFORNIA, REPORT AND RECOMMENDATIONS OF THE JUDICIAL COUNCIL ADVISORY COMMITTEE ON PRIVATE JUDGES 17 (1990) [hereinafter REPORT AND RECOMMENDATIONS].

78. See, e.g., id. (citing the California Judicial Retirement Study (National Center for State Courts, 1988), which found that less than a third of the 64 rent-a-judges surveyed had retired early); JANICE A. ROEHL ET AL., INSTITUTE FOR SOCIAL ANALYSIS, PRIVATE JUDGING: A STUDY OF ITS VOLUME, NATURE, AND IMPACT ON STATE COURTS, 13 (1993); Don J. DeBenedictis, Study OKs Rent-a-Judge, A.B.A. J., Nov. 1990, at 41.

79. ROEHL ET AL, supra note 78, at 13.

80. Id.

81. Thompson, supra note 4 , at 44 . 
In about 1,224 hours, 17 minutes and 40 seconds, LES [Olson] will retire from the formal life of a sitting Judge and, with computer in hand, slide rather comfortably into the posh and cushy role of private Judge (retired) with trailing calendar and preprinted bills (medium three-figure range) for services to be rendered; Join us in wishing LES all the best and much \$uq̣e $\$ .^{82}$

Although judges may not be retiring early, the consensus is that judges are retiring as soon as they can. ${ }^{83}$ As Judge Olson himself said, "[F]ew judges have remained in active service after the required 20 years of service. Some judges, of course, return to the practice of law. Some retire to trim roses or take world cruises. But many become rent-a-judges." ${ }^{~} 44$ Although the retirement of judges may not be causing a shortage on the active bench, some say that fewer retired judges are available for emergency courthouse assignments. ${ }^{85}$

Judging for profit also has produced other interesting side effects. Judges who once made their living intimidating lawyers now must go about courting them, and some judges report a marked change in their courtroom demeanor. One such judge, Jack Tenner, had a tough reputation on the bench but reportedly calmed down once he entered the private judge market. ${ }^{86} \mathrm{He}$ admitted that "[s]ome miserable son-of-a-bitch on the bench becomes the nicest guy in the world when he becomes a private judge." 87

Another reported side effect is what some would call the natural result of working by the hour. One attorney reported to

82. Id. Olson is today one of the most sought-after rent-a-judges in the state. Id. at 43. Outside California, the most famous rent-a-judge of them all may be Joseph Wapner of television's The People's Court. Cox, supra note 58, at 23.

83. REPORT AND RECOMMENDATIONS, supra note 77, at 18; DeBenedictis, supra note 78 , at 41 .

84. Olson, supra note 33 , at 39 .

85. Cox, supra note 58, at 23. Cox quotes William E. Davis, director of the Administrative Office of the Courts, as saying that the pool of retired judges has "shrunk significantly." Id.

86. Guccione, supra note 4, at 35.

87. Id. Some judges, on the other hand, try to capitalize on their tough reputations. When Judge Ira Brown joined JAMS, the company ran an ad showing two openmouthed sharks with the caption "Just when you thought it was safe to come to JAMS ...."Id. Although some would argue that turning judges into nicer human beings is a beneficial side effect of rent-a-judging, judges' changing their personalities to suit their customers and sell their services raises disturbing implications about judicial impartiality. Those with great faith in the corrective powers of the free market, however, would argue that bias would in fact be eliminated, not encouraged. 
the National Law Journal about a rent-a-judge who spent nineteen days hearing oral arguments for an injunction. "I couldn't even get him to take judicial notice that L.A. has smog," the attorney said. ${ }^{89}$ The total bill: $\$ 80,000 .^{90}$ Such behavior should obviously be very rare, because the goal of each rent-a-judge is to attract repeat business. What is troublesome, however, is that judges are modifying their behavior to attract and keep business. Defenders argue that judges behave nore fairly in rent-a-judge proceedings than in standard proceedings because a reputation for partiality can quickly derail a blossoming practice. There may be situations, however, in which a rent-a-judge presides over a trial involving a repeat customer on one side and a first-timer on the other; such a rent-a-judge would certainly face more temptation toward bias. ${ }^{91}$ Moreover, this type of bias would be encouraged, not discouraged, by market forces because the goal of a rent-a-judge is to attract and keep repeat players who can provide a steady income. The market provides rent-a-judges with no incentive to accord equal favor to one-time customers. ${ }^{92}$

3. The Volume of Rent-a-Judge Proceedings. The number of rent-a-judge proceedings is very sinall compared to the total number of cases filed in the California state courts. Although the total numbers of references and private temporary judge proceedings are unavailable ${ }^{93}$ it may be possible to extrapolate a rough total from figures given by practitioners. According to Sheri Stoyanoff, operations manager for the JAMS Orange County Regional Office, JAMS judges in Orange County handle approximately twenty proceedings a month as referees or private temporary judges. ${ }^{94}$

88. Cox, supra note 58, at 23.

89. Id. (quoting attorney Joel S. Moskowitz).

90. Id.

91. The Judicial Council of California has taken a first step toward remedying this difficulty by promulgating new rules requiring rent-a-judges to disclose prior employment. See CAL. R. CT. 244(c), 532(c) (applying to temporary judges); id. 244.1(b), 532.1(b) (applying to referees).

92. It would be fallacious to assume that both sides in a dispute always are equally sophisticated and either know or have the resources to discover a particular rent-a-judge's "track record."

93. California's Administrative Office of the Courts does not keep track of privately judged cases. REPORT AND RECOMMENDATIONS, supra note 77, at 23. The report laments the lack of data on the number of rent-a-judge cases and the types of disputes involved. The Judicial Council Advisory Committee on Private Judges recommended that the Judicial Council of California conduct a comprehensive study to gather this data. Id.

94. Telephone Interview with Sheri Stoyanoff, Operating Manager, JAMS (Oct. 20, 
Stoyanoff said, however, that the bulk of the reference proceedings involve only discovery matters. ${ }^{95}$ In such proceedings, the rent-ajudge handles all pre-trial and discovery motions; the public court handles the actual trial. The Orange County JAMS office handles only about two full-blown private trials a month. ${ }^{96}$ In total, JAMS handles 240 reference proceedings a year in Orange County, and perhaps only about two dozen of these are complete trials. Compare these figures with a total of 53,929 civil filings in Orange County in fiscal 1991-1992, and the total number of rent-a-judge proceedings handled by JAMS appears miniscule. ${ }^{97}$ One commentator estimates that private judges handled only 0.089 percent of all civil trial dispositions statewide in $1988 .^{98}$ Another study published in March 1993 by the Institute for Social Analysis estimated the number of private trials in 1991 at only between 200 and 300 statewide. ${ }^{99}$

Defenders of the rent-a-judge system may point to its infrequent use as proof that private judges have not damaged the public court system. In fact, they say, it has made no difference at all. The current surge in the use of rent-a-judges is still a recent phenomenon, however, and the fact that relatively few people use

1993). JAMS is used as an example for this purpose because it controls approximately $60 \%$ of the ADR market in California. Telephone Interview with John J. Welsh, General Counsel, JAMS, supra note 60.

95. Telephone Interview with Sherri Stoyanoff, supra note 94.

96. Id.

97. Judicial Council of California, ANnual Data Reference, 1991-92 CaSeLOAD DATA BY INDIVIDUAL COURTS 13-26 (1992). These figures include filings in probate and family courts as well as single-party petitions.

98. Richard Chernick, What's Wrong with Private Judging, LOS ANGELES LAw., Nov. 1989, at 19, 20. In fiscal 1991-1992, there were 703,791 civil cases filed in the superior courts. JUDICIAL COUNCIL OF CALIFORNIA, 1993 ANNUAL REPORT, VOL. II: ANNUAL Report of the Administrative Office of the California Courts, Superior Court Table 6. Again, this figure includes filings in probate and family courts as well as singleparty petitions.

99. ROEHL ET AL., supra note 78, at 8 . This study extrapolated from several sources: court records from three counties; a survey of judges, both active and retired; and information about JAMS (it is significant to note, however, that JAMS did not take part in this study or contribute information). Id. at 8-9. The study based its conclusion on 134 cases it identified as "thonght to be privately judged," $i d$. at 6 , and on survey responses from 151 private judges. The researchers do not state what criteria they used in determining which cases were "thought to be privately judged." See id. The information about JAMS cited in this study consists of a single reference to an article published April 23, 1991, in the Orange County Register. This article quotes JAMS Chief Judicial Officer John Trotter as saying that only about 50 of the 10,000 cases JAMS heard from April 1990 to March 1991 were full-blown trials. Id. at 9. 
rent-a-judges today does not mean that few will use them in twenty years. Moreover, the low number of rent-a-judge proceedings does not mdicate that rent-a-judges are unpopular; it could mean instead that rent-a-judges are inaccessible to the average litigant. Furthermore, the primary concern should not be the number of cases diverted from the public system but the types of issues that rent-a-judges decide. A single case could have far-ranging public effects.

\section{The CONSTItUTIONALITY OF THE RENT-A-JUDGE SYSTEM UNDER CALIFORNIA LAW}

Previous attacks on the rent-a-judge system have primarily focused on its constitutionality under the Due Process and Equal Protection Clauses of the Federal Constitution. ${ }^{100}$ Defenders of the system have found neither attack convincing, ${ }^{101}$ and in truth, neither argument appears persuasive, given the current state of federal constitutional law. ${ }^{102}$ The California state constitution, however, may provide a more effective weapon in an attack on private judging. ${ }^{103}$ The liberal view of California courts toward court access and equal protection support a cogent argument that the rent-a-judge system is unconstitutional under state law. ${ }^{104}$

100. Note, The California Rent-a-Judge Experiment: Constitutional and Policy Considerations of Pay-As-You-Go Courts, 94 HARV. L. REV. 1592 (1981).

101. See, e.g., Christensen, supra note 24, at 90-93; Stephen K. Haynes, Comment, Private Means to Public Ends: Implications of the Private Judging Phenomenon in California, 17 U.C. DAVIS L. REV. 611, 622-35 (1984); Newton \& Swenson, supra note 10, at 816-19; Shapiro, supra note 10, at 293-305.

102. The equal protection argument would likely fail under federal constitutional law because of the U.S. Supreme Court's ruling in San Antonio Indep. Sch. Dist. v. Rodriguez, 411 U.S. 1, 23-28 (1973), that wealth is not a "suspect class." Thus, one cannot argue that the rent-a-judge system violates equal protection by discriminating against those who are not wealthy enough to be able to afford rent-a-judge services. As to the due process argument, see infra note 109 and accompanying text.

103. State constitutions often provide more expansive rights than does the Federal Constitution. For one perspective on this issue, see Martha I. Morgan, Fundamental State Rights: A New Basis for Strict Scrutiny in Federal Equal Protection Review, 17 GA. L. REv. 77 (1982).

104. A preliminary issue is whether the California Constitution itself precludes an attack on state constitutional grounds because it specifically authorizes the use of temporary judges. CAL. CONST. art. VI, § 21. (Referees, however, are authorized by statute, CAL. Civ. Proc. CODE $\S \S 638-645$ (West 1993 \& Supp. 1994), and are thus not immune from a state constitutional attack.) Although the California Constitution authorizes the appointment of temporary judges, it does not specifically authorize the appointment of privately paid temporary judges. Article V1 is silent on the issue of payment. Until re- 
This Part argues primarily that the rent-a-judge system violates equal protection under California law. ${ }^{105}$ It also outlines a possible due process attack, although that argument is likely to fail because it calls on the courts to take what could be an overly expansive view of the state-guaranteed right of "timely access" to the courts. ${ }^{106}$

\section{A. Due Process Under the California Constitution}

The right of access to the courts is significantly broader under California law than under the Federal Constitution. In Earls v. Superior Court, ${ }^{107}$ the California Supreme Court held that "[i]ndigents are entitled not merely to access to the courts but to timely access." 108 The U.S. Supreme Court, however, has held that due process requires only that a state "afford to all individuals a meaningful opportunity to be heard." ${ }^{109}$ Thus, to attack the rent-

cently, all temporary judges have been paid by the state, $i d$., and their primary use has been to help clear backlogs in the public courts. Facially-and as historically applied-article VI does not conflict with the due process and equal protection clauses of the California Constitution. An argument that article VI is meant to limit due process and equal protection guarantees is thus not compelling.

105. California's due process and equal protection clauses are found in article $I, \S 7$ of the state constitution. In pertinent part, this section provides that "[a] person may not be deprived of life, liberty, or property without due process of law or denied equal protection of the laws ...." CAL. CONST. art. I, \& 7(a).

106. If a court were to find the rent-a-judge system unconstitutional, it could grant one of two remedies: abolishing the rent-a-judge system or requiring the state to pay rent-a-judge fees for indigent litigants. On balance, the first option is preferable. Abolishing the rent-a-judge system would mean that everyone, rich or poor, would suffer long delays in the public courts, possibly creating more incentive for reform. If the state were to pay the rent-a-judge fees of indigent litigants, however, the result would be less money for the public courts and less incentive for reform.

107. 490 P.2d 814 (Cal. 1971).

108. Id. at 818 (emphasis added). Subsequent decisions of the California Supreme Court have reiterated the entitlement to timely access. See, e.g., Payne v. Superior Court, 553 P.2d 565, 576 (Cal. 1976); March v. Municipal Court, 498 P.2d 437. 441 (Cal. 1972); In re Marriage of Reese, 140 Cal. Rptr. 589, 591 (Ct. App. 1977).

109. Boddie v. Connecticut, 401 U.S. 371, 379 (1971). Moreover, the Court has held that indigents do not have a fundamental right of access to the courts. In Boddie, the Supreme Court struck down as unconstitutional a $\$ 60$ filing fee for persons wanting a divorce. At the same time, however, the Court refused to hold that "access for all individuals to the courts is a right that is, in all circumstances, guaranteed by the Due Process Clause of the Fourteenth Amendment ...."Id. at 382. Two years later, in Ortwein v. Schwab, 410 U.S. 656, 661 (1973), and United States v. Kras, 409 U.S. 434, 450 (1973), the Court upheld filing fees for civil appeals and bankruptcies. In these cases, the Court held that access to the courts depends on the nature of the right at stake. 
a-judge system under federal law, one must argue that the public courts are so slow and meaningless that they do not provide a "meaningful opportunity to be heard" and that no one except a rent-a-judge can provide adequate due process. ${ }^{110}$ Such an argument is obviously unworkable because it challenges the validity of the entire state court system. ${ }^{111}$

California law, however, may support a more plausible due process argument against rent-a-judges, although not a compelling one. As stated before, California law guarantees not only access to the courts but "timely access." Inability to afford a rent-ajudge-and the speedy judgment that comes with him-arguably could be an unconstitutional denial of timely access, especially in cases where time is of the essence. ${ }^{112}$ Few California cases, however, have interpreted the right to timely access, and it is unclear how broad this entitlement is.

The California Supreme Court has defined the entitlement rather narrowly. ${ }^{113}$ In Earls v. Superior Court, the court reversed a lower court decision denying the plaintiff's application to file in forma pauperis. ${ }^{114}$ In rejecting a request for a fee waiver, the lower court had told the plaintiff to save up money and file suit later. ${ }^{115}$ The California Supreme Court held that the lower court had denied the plaintiff her right to "timely access."116 Courts cannot refuse to waive filing fees, the court held, just because an indigent litigant "may, over a period of months, succeed in accumulating the amount necessary to defray his costs."117 In the context of this case, timely access meant only that an indigent lit-

110. Note, supra note 100 , at 1607 .

111. Id. at 1607 n.85.

112. In Los Angeles, civil cases can take up to five years to get to trial. REPORT AND RECOMMENDATIONS, supra note 77, at 13 . Delay is admittedly often to the advantage of one party. However, there are also many situations in which both sides would prefer a speedy resolution of the dispute. Arbitration is an option, but both sides must give up any right of appeal. Rent-a-judge proceedings provide the best of both worlds-a speedy judgment and a right of appeal.

113. See Earis v. Superior Court, 490 P.2d 814, 818-19 (Cal. 1971). Since Earls, the California Supreme Court has not further interpreted the right to timely access.

114. Id. at 814 .

115. Id. at 818 .

116. Id.

117. Id. The court in March v. Municipal Court, 498 P.2d 437, 441 (Cal. 1972), followed Earls and held that an indigent litigant cannot be denied a transcript just because she can buy one later with future earnings. 
igant should not endure "unreasonable delays"118 in the initial filing of his suit.

In a later case, In re Marriage of Reese, ${ }^{119}$ however, the California Court of Appeal broadened the right of timely access to include a right to timely judgment. ${ }^{120}$ This case held that a court cannot withhold final judgment until an indigent litigant pays costs. ${ }^{121}$ The court held that the right to timely access is "not limited to prepayment of filing fees but includes proceeding to final judgment." ${ }^{122}$ Because this case was not appealed, it is unclear whether the California Supreme Court would agree with this broader interpretation. ${ }^{123}$ If the right of timely access means only a right to "timely filing," lack of access to a rent-a-judge is not a violation of due process under California law. Inability to afford a rent-a-judge does not prevent indigent litigants from filing suit. However, if the right of timely access also means a right to timely judgment, a liberal court could hold denial of access to a rent-ajudge to be unconstitutional. An inability to afford the services of a rent-a-judge could mean that an indigent litigant must wait years for a judgment that could otherwise be available in a matter of months.

Such a holding is admittedly unlikely. Even broadly interpreted, a right to timely judgment does not necessarily mean a right to the fastest possible judgment; it may mean only that indigent litigants should not face undue obstacles in obtaining a final judgment. Moreover, a rent-a-judge can be viewed as a privilege-a "deluxe" feature of the court system to which the minimal guarantees of due process do not apply. If due process does not entitle indigent civil litigants to appointed counsel ${ }^{124}$ or free tran-

118. Earls, 490 P.2d at 818.

119. 140 Cal. Rptr. 589 (Ct. App. 1977).

120. The plaintiff had initially been allowed to proceed in forma pauperis, but the trial court later changed its mind and ordered the plaintiff to pay filing fees. Id. at 591 . Although the court had already granted the plaintiff a divorce, it refused to enter final judgment until the plaintiff paid his fees. Id.

121. Id. at 592 .

122. Id.

123. Although the California Supreme Court has heard several cases on the right of access to the courts, see, e.g., Payne v. Superior Court, 553 P.2d 565 (Cal. 1976), the court has not interpreted the right of "timely access" since Earls. The California Court of Appeal, however, followed Reese in In re Marriage of Sanabia, 157 Cal. Rptr. 56 (Ct. App. 1979). As in Reese, the court held that entry of final judgment cannot be conditioned upon the payment of filing fees. Id. at 57.

124. Nick v. Department of Motor Vehicles, 16 Cal. Rptr. 2d 305, 309-10 (Ct. App. 
scripts, ${ }^{125}$ it likely does not entitle them to the luxury of a rented judge. ${ }^{126}$

\section{B. Equal Protection Under California Law}

A more compelling argument against the rent-a-judge system is that it violates equal protection under California law. By denying poorer litigants access to rent-a-judges, the state denies equal access to a state-sponsored benefit. Several prior commentators have contended that the rent-a-judge system violates equal protection under federal law, ${ }^{127}$ but this argument has foundered on the fact that the U.S. Supreme Court has never held wealth alone to be a suspect classification. ${ }^{128}$ In California, however, the state supreme court has taken a more expansive view and held that wealth alone can be a suspect classification. In California courts, as in the federal courts, strict scrutiny applies to an allegedly discriminatory statute if it affects a "fundamental interest" or involves a "suspect" class. ${ }^{129}$ In Serrano $v$. Priest ${ }^{130}$ the state supreme court expanded the category of these suspect classifications to include wealth distinctions. In this case, the court invalidated the state's school financing scheme because of the overwhelming disparities among districts in the amount of per-pupil revenue. ${ }^{131}$ The court held that this inequality unconstitutionally discriminated

1993) (holding that indigent is not entitled to appointed counsel in civil suits or administrative hearings).

125. Civil Serv. Comm'n v. Superior Court, 133 Cal. Rptr. 825, 827 (Ct. App. 1976) (holding that indigent seeking review of administrative hearing is not entitled to a free transcript); Leslie v. Roe, 116 Cal. Rptr. 386, 388 (Ct. App. 1974) (holding that free transcripts are unavailable to indigent civil plaintiffs who wish to appeal).

126. An even more tenuous due process argument against rent-a-judge proceedings would be that the state, by creating rent-a-judges, has also created a due process property interest in a speedy judgment. By creating the rent-a-judge system, California has given litigants the right to get judgments today instead of several years from now. This right, however, is not accessible to everyone. See Note, supra note 100 , at 1602 , for a similar argument that the rent-a-judge system deprives litigants of a property interest by diminishing the value of their interests in their suits (as opposed to the argument proposed here that the system creates a separate property right to a speedy judgment).

127. See, e.g., id. at 1601; Robert Gnaizda, Secret Justice for the Privileged Few, JuDICATURE, June-July 1982, at 6,11.

128. See, e.g., Harris v. McRae, 448 U.S. 297, 321-26 (1980); Maher v. Roe, 432 U.S. 464, 471 (1977); San Antonio Indep. Sch. Dist. v. Rodriguez, 411 U.S. 1, 29 (1973); Dandridge v. Williams, 397 U.S. 471, 485 (1970).

129. See, e.g., In re Antazo, 473 P.2d 999, 1005 (Cal. 1970).

130. 487 P.2d 1241, 1252 (Cal. 1971).

131. Id. at 1251. 
against students living in less affluent districts. ${ }^{132}$ Significantly, the court held that such discrimination need not be intended to be unlawful. ${ }^{133} \mathrm{De}$ facto, as well as de jure, discrimination is unconstitutional. ${ }^{134}$ Since Serrano, the California state courts have continued to hold that wealth is a suspect classification demanding strict scrutiny. ${ }^{135}$

Despite this general rule, California courts have been somewhat reluctant to find impermissible classifications based on wealth. ${ }^{136}$ This conservative view of wealth classifications is understandable in that an overly broad view would lead to the invalidation of any statute that has the indirect effect of imposing a greater burden on poor people than on wealthy ones. Taken to an extreme, such reasoning could imply that anything from auto registration fees to taxes ${ }^{137}$ could be challenged on equal protection grounds. In light of this reluctance, it may not be immediately obvious that the California courts would be willing to strike down the rent-a-judge system as a violation of equal protection. An analysis of the caselaw, however, demonstrates that such a challenge could be successful.

In general, California courts have found that an impermissible wealth classification exists when a person's lack of wealth denies him equal access to an important state-sponsored right. In Serrano

132. Id. at 1255.

133. Id. at $1253-54$.

134. Quoting Hobson v. Hansen, 269 F. Supp. 401 , 497 (D.D.C. 1967), the court said that "the arbitrary quality of thoughtlessness can be as disastrous and unfair to private rights and the public interest as the perversity of a willful scheme." Serrano, 487 P.2d at 1254 n.18.

135. See, e.g., Charles S. v. Superior Court, 653 P.2d 648, 654 (Cal. 1982); Swoap v. Superior Court, 516 P.2d 840, 850 (Cal. 1973); In re Antazo, 473 P.2d 999, 1006 (Cal. 1970); Vehicular Resident Ass'n v. Agnos, 272 Cal. Rptr. 216, 219 (Ct. App. 1990); Miller v. Murphy, 191 Cal. Rptr. 740, 748 (Ct. App. 1983); Inmates of Sybil Brand Inst. for Women v. County of Los Angeles, 181 Cal. Rptr. 599, 603-04 (Ct. App. 1982).

136. See, e.g., Swoap, 516 P.2d at 840 (upholding a statute requiring adult children to reimburse the state for welfare payments to their parents, even though this requirement put a bigger burden on indigents); Wood v. Public Utilities Comm'n, 481 P.2d 823 (Cal. 1971) (upholding the utility commission's credit rules that required customers to pay a deposit if they could not establish good credit), appeal dismissed, 404 U.S. 931 (1971); County of Los Angeles v. Patrick, 14 Cal. Rptr. 2d 665 (Ct. App. 1992) (upholding a statute that denies discretionary reductions in child support payments if the child is living with a parent on welfare).

137. This is not to say, of course, that an extremely regressive tax could not quite possibly be challenged successfully on equal protection grounds. 
v. Priest, ${ }^{138}$ the California Supreme Court held that the quality of a child's public school education cannot depend on his family's wealth. ${ }^{139}$ This was also the case in Hartzell $v$. Connell, ${ }^{140}$ in which the California Supreme Court held that schools cannot charge activity fees for children who want to participate in extracurricular arts or sports programs. ${ }^{141}$ However, the California state courts have refused to find wealth-based discrimination if a statute merely affects larger numbers of poor people than wealthy ones. For example, in Miller v. Murphy, ${ }^{142}$ the court of appeal rejected a challenge to a municipal regulation that requires pawnshop owners to ask their customers for fingerprints and identification. Even though poor people are more likely than the wealthy to visit pawnshops, the court held that the regulation does not discriminate against the poor. ${ }^{143}$ Instead, it distinguishes between those who visit pawnshops and those who do not. ${ }^{144}$ Similarly, in Vehicular Residents Association v. Agnos, ${ }^{145}$ the court of appeal upheld an ordinance banning people living in motor homes from parking im certain public areas at night. The court held that the ordinance does not discriminate against the poor because wealthy people also use motor homes and the ordinance applies equally to them. ${ }^{146}$

In sum, the cases discussed imply that California courts will find impermissible wealth-based discrimination if (1) the lack of wealth results in the denial of an important state-sponsored bene$\mathrm{fit}^{147}$ or (2) the challenged statute or practice discriminates di-

138. 487 P.2d 1241 (Cal. 1971).

139. Id. at 1244. ("[The funding system] invidiously discriminates against the poor because it makes the quality of a child's education a function of the wealth of his parents and neighbors.").

140. 679 P.2d 35 (Cal. 1984).

141. Id. at 44. But see Arcadia Unified Sch. Dist. v. State Dep't of Educ., 825 P.2d 438 (Cal. 1992), in which the court upheld a statute authorizing school districts to charge students fees for bus transportation. What saved that statute, however, was a provision exempting poor students from the fees. Id. at $447-48$.

142. 191 Cal. Rptr. 740 (Ct. App. 1983).

143. Id. at 748.

144. Id. Moreover, the court said, pawnshop customers are not universally poor. Id.

145. 272 Cal. Rptr. 216 (Ct. App. 1990).

146. Id. at 219. In another case based on the same rationale, the court of appeal upheld a state statute allowing creditors to garnish debtor's wages for debts incurred "for the 'common necessaries of life' . . ." Thayer v. Madigan, 125 Cal. Rptr. 28, 29 (Dist. Ct. App. 1975). The court held that the statute disadvantaged not the poor but an "indeterminate, and doubtless varying, class of persons who use their earnings to pay for the necessaries of life ...."Id. at 30.

147. Hartzell v. Connell, 679 P.2d 35 (Cal. 1984); Serrano v. Priest, 487 P.2d 1241 
rectly and solely against the poor. ${ }^{148}$ The rent-a-judge system fits both of these criteria. Rent-a-judges are available only to those who can afford them, and moreover, lack of access to a rent-ajudge deprives poorer litigants of an important state-sponsored benefit-that is, the rent-a-judge himself. ${ }^{149}$

Some may argue, however, that the rent-a-judge system does not violate equal protection because it is, in fact, a luxury and not an important state-sponsored benefit. ${ }^{150}$ As one rent-a-judge defender put it,

It may be true that only the rich can afford private judging. But it is also true that only the rich can afford private schooling, private hospitals, better lawyers and bigger houses. There is nothing unconstitutional about the fact that the rich have advantages in this country .... As long as the wealthy do not unconstitutionally deprive the poor of protected liberty rights, this access to superior facilities is constitutionally acceptable..$^{\text {51 }}$

If this conception is accurate, rent-a-judge proceedings arguably would be constitutional under California law. Poorer litigants are not entitled to all the frills that wealthier hitigants enjoy. ${ }^{152}$

\section{(Cal. 1971).}

148. Vehicular Residents Ass'n, 272 Cal. Rptr. at 216; Miller v. Murphy, 191 Cal. Rptr. 740 (Ct. App. 1983); Thayer, 125 Cal. Rptr. at 28.

149. Or more accurately, denial of access to a rent-a-judge denies litigants the benefit of a speedy, convenient, efficient, and private state court trial.

150. This argument was discussed supra text accompanying notes $124-26$, in connection with the due process argument against the rent-a-judge system. Although the argument may be persuasive in that context, it fails in this one. Even though due process may not require access to a rent-a-judge, equal protection requires evenhanded distribution of state-conferred benefits.

151. Shapiro, supra note 10 , at 313-14.

152. Indigent civil litigants are entitled to an absolute waiver of filing fees and other costs. Nick v. Department of Motor Vehicles, 16 Cal. Rptr. 2d 305, 310 (Ct. App.) (holding that indigent may petition for waiver of $\$ 150$ witness fee required to compel state trooper to attend license-suspension hearing), cert. denied, 114 S. Ct. 397 (1993); see supra notes 113-17 and accompanying text. They are not, however, necessarily entitled to free transcripts, free interpreters, or appointed counsel. Jara v. Municipal Court, 578 P.2d 94, 96 (Cal. 1978) (holding that litigant was not entitled to a free interpreter), cert. denied, 439 U.S. 1067 (1979); Civil Serv. Comm'n v. Superior Court, 133 Cal. Rptr. 825, 827 (Ct. App. 1976) (holding that indigent seeking review of administrative hearing is not entitled to a free transcript); Leslie v. Roe, 116 Cal. Rptr. 386, 387 (Ct. App. 1974) (holding that free transcripts are unavailable to indigent civil plaintiffs who wish to appeal). In Jara, however, the litigant was represented by counsel, who did know English and presumably understood the proceedings. If the litigant had been unrepresented, he would have been entitled to a free interpreter. Nick, $16 \mathrm{Cal}$. Rptr. $2 \mathrm{~d}$ at 309 (noting that indigent is not entitled to appointed counsel in civil suits or administrative hearings). 
Rent-a-judges, however, are not mere frills, ${ }^{153}$ and litigants who use rent-a-judges are not opting out of the public system the way private school students have opted out of the public schools. Rent-a-judges are an inextricable part of the official state judicial system. They are statutorily authorized, and their judgments are honored as any other state court judgment would be. ${ }^{154}$ Unlike the decisions of private arbitrators, rent-a-judge judgments can be appealed on the merits and cited as precedent. ${ }^{155}$ Moreover, renta-judges enjoy many of the same powers that sitting judges do, including the power to call juries ${ }^{156}$ and to hold parties in contempt. ${ }^{157}$ In addition, unlike private arbitrators and mediators, rent-a-judges have access to publicly funded resources. Rent-ajudges may call their juries from the county jury pool and have been allowed to hold proceedings in public courthouses. ${ }^{158}$ In sum, rent-a-judges are very much a part of the state judicial system, ${ }^{159}$ but a part to which only a few have access. ${ }^{160}$ Analogously, suppose that all children must attend a single school run by the state. The school is free, but students have the option of paying $\$ 10,000$ a year for a Harvard-educated teacher, brand-new textbooks (which the regular students will get next year), and a larger variety of classes. In addition, the students get a private lunchroom with gourmet food. Next door, the regular students must make do with overcrowded classrooms, outdated books and

153. Even if the use of rent-a-judges were a frill, equal protection might still apply. Commentators have pointed out that the U.S. Supreme Court "has repeatedly held states to a standard of evenhandedness in cases in which a state monopolizes the distribution of a good." Note, supra note 100, at 1604. The Note cited examples such as federal civil service employment, Hampton v. Mow Sun Wong, 426 U.S. 88 (1976); food stamps, United States Dep't of Agric. v. Moreno, 413 U.S. 528 (1973); tuition at a state university, Vlandis v. Kline, 412 U.S. 441 (1973); ballot access, Bullock v. Carter, 405 U.S. 134 (1972); drivers' licenses, Bell v. Burson, 402 U.S. 535 (1971); and voting, Reynolds v. Sims, 377 U.S. 533 (1964).

154. See supra notes 13-24 and accompanying text.

155. Id.; see also CAL. Crv. Proc. CODE § 645 (West Supp. 1994).

156. See supra notes $38-44$ and accompanying text.

157. See supra notes $34-37$ and accompanying text.

158. See supra notes $43-46$ and accompanying text.

159. This is also the crucial difference between rent-a-judges, who are state-sponsored, and arbitrators and mediators, who are wholly private.

160. In contrast, access to the courts was not an issue in the cases involving transcripts and appointed counsel. It was a given that the litigants were to have their day in court, though the lack of counsel and other benefits might handicap their case. A litigant who lacks access to a rent-a-judge, on the other hand, lacks all access to a benefit available to wealthier litigants-a trial on demand. 
broken lab equipment. Only the most hard-hearted would find such state-sponsored discrimination to be permissible. Yet the renta-judge system is little different. The state provides convenient, fast-track justice only to those who can pay for it. The rent-ajudge system undeniably and unconstitutionally favors the wealthy.

Although wealth discrimination is suspect in California, a statute found to discriminate on that basis may still survive if it passes strict scrutiny. ${ }^{161}$ But absent a compelling state interest for which the use of rent-a-judges is necessary, the rent-a-judge system must be held unconstitutional. The only state interest rent-a-judges can help promote is the interest in easing the congestion in the courts. Even if such an interest is compelling, rent-a-judges are hardly necessary to achieve it. First of all, not enough people use rent-a-judges to make much of a dent in the backlog. ${ }^{162}$ In fiscal 1991-1992, there were 703,791 civil cases filed in the California courts. ${ }^{163}$ Rent-a-judge proceedings would have to number in the thousands for the public courts to feel less crowded. Moreover, nondiscriminatory means are available for easing court congestion. ${ }^{164}$ In fact, equal protection demands that the California legislature choose a nondiscriminatory option from the myriad options available.

\section{Rent-A-Judges ANd Public Policy}

In some ways, the rent-a-judge system seems to be an ideal hybrid of public and private justice. It offers the speed, efficiency, and convenience of arbitration and mediation along with an enforceable, appealable state court judgment. Although individual litigants have undoubtedly benefitted from rent-a-judges, the public interest has not. Unanswered are many troubling questions about the permissible scope of a rent-a-judge's authority and the role rent-a-judges should play in the state judicial system. Also troubling are the effects that rent-a-judges have on the public courts and their potential for eroding the courts' authority. Ultimately, as this Part argues, the rent-a-judge system puts too much public power into private hands.

161. Serrano v. Priest, 487 P.2d 1241, 1259 (Cal. 1971).

162. See supra notes $93-99$ and accompanying text.

163. Judicial COUNCIL OF CALIFORNIA, supra note 97, at 13-26 (totaling all petitions filed in the California superior courts).

164. For example, courts can limit the length of trials or hire more judges. 


\section{A. Rent-a-Judges and the Authority of the Courts}

The primary purpose of a judicial system, whether public or private, is to settle disputes. ${ }^{165}$ The byproduct of that function is rulemaking. ${ }^{166}$ In private justice, rulemaking is of little concern; litigants pay arbitrators and mediators to resolve only the dispute at hand. Moreover, citizens do not look to arbitrators and mediators to formulate rules for society. ${ }^{167}$ In the public courts, however, rulemaking takes on far greater importance. Public courts play a pivotal role in society: "Their job is not to maximize the ends of private parties, nor simply to secure the peace, but to explicate and give force to the values embodied in authoritative texts such as the Constitution and statutes: to interpret those values and to bring reality into accord with them."168 The public courts, when they speak, speak not only for the government but for society. ${ }^{169}$ Thus, their decisions carry far greater social weight than the decisions of private tribunals. ${ }^{170}$

The rent-a-judge system, however, blurs and devalues this distinction between public and private tribunals. Although they are nominally members of the state judiciary, rent-a-judges are chosen by the litigants, and they offer individualized, ${ }^{171}$ private justice, much like arbitrators and mediators. Consequently, their decisions carry less force and legitimacy in the eyes of the public than those of wholly public courts. Much of the power of the public courts to speak for society comes from their public accountability:

Adjudication uses public resources, and employs not strangers chosen by the parties but public officials chosen by a process in which the public participates. These officials, like members of the legislative and executive branches, possess a power that has been defined and conferred by public law, not by private agreement. $^{172}$

165. William M. Landes \& Richard A. Posner, Adjudication as a Private Good, $8 \mathrm{~J}$. LEGAL STUD. 235, 236 (1979).

166. Id.

167. See id. at 240 .

168. Owen Fiss, Comment, Against Settlement, 93 YALE L.J. 1073, 1085 (1984).

169. Geoffrey C. Hazard, Jr. \& Paul D. Scott, The Public Nature of Private Adjudication, 6 YALE L. \& POL'Y REV. 42, 57 (1988).

170. Id.

171. Everything is within the litigants' control, such as the time, place, and rules for trial and the identity of the judge. See supra notes 25-28 and accompanying text.

172. Fiss, supra note 168 , at 1085. 
Rent-a-judges, however, are chosen by private agreement, and the market is the only external check upon their behavior. The system itself imposes no quality control over the judges; consent of the litigants is the only requirement for the appointment of a rent-ajudge. ${ }^{173}$ California's general reference statutes state no qualifications that rent-a-judges must meet. ${ }^{174}$ Unlike their public court counterparts, rent-a-judges do not pass through the screening process of public election or governmental appointment. Moreover, there is no disciplining body for rent-a-judges, ${ }^{175}$ and unlike other public court judges, rent-a-judges apparently cannot be impeached or recalled. Thus, despite their public role, rent-a-judges are not publicly accountable. Although rent-a-judges nominally enjoy the authority of the state, this authority is undermined by the lack of a public mandate. Because rent-a-judges do not have the same institutional backing as their public court brethren, their judgments lack the public weight and authority of other state court rulings. ${ }^{176}$

The element of choice also diminishes the authority of rent-ajudge judgments. The rent-a-judge system creates a buyer's market that the hitigants control, and the judges must tailor their reputations and their decisionmaking to attract customers. As noted above, some California rent-a-judges have even toned down their personalities to make themselves more marketable. ${ }^{177}$ The rent-ajudge system upends the usual balance of power between judges and litigants. ${ }^{178}$ Moreover, the power of choice vested in litigants diminishes the threat of state authority, which is a chief source of power for the courts: "Among other things, government sanction

173. See supra notes 13, 19 and accompanying text. Again, some may argue that the free market imposes the best quality control of all.

174. Id,

175. See Gnaizda, supra note 127, at 12; Thomas S. Vangel, Private Judging in California: Ethical Concerns and Constitutional Considerations, 23 NEW ENG. L. REV. 363, 376 (1988).

176. This argument, though possibly applicable, is not directed at wholly private methods of dispute resolution, such as binding arbitration. Private arbitrators and mediators do not pretend to assume the mantle of the state in issuing their judgments, and their decisions are not given the same weight as rent-a-judge judgments because they cannot be appealed on the merits or treated as precedent. Legitimacy in the eyes of the public is not a concern for private arbitrators, nor is it intended to be.

177. See supra note 87 and accompanying text.

178. This result is especially peculiar because litigants, by filing suit, call on the authority of the state to hear their case. 
implies the direct threat of compulsion by the state [and gives judgments] a degree of clarity and forcefulness." 179 The ability to choose a judge, however, enables litigants to shape the ultimate judgment. And where the ultimate goal is customer satisfaction, rent-a-judges are also likely to de-emphasize their coercive powers as agents of the state. Thus by empowering litigants, the rent-ajudge system weakens the judiciary. ${ }^{180}$

\section{B. Rent-a-judges and the Rule of Law}

As noted above, rulemaking is a crucial function of the public courts. It is a function, however, that rent-a-judges cannot adequately perform. A rent-a-judge's public-private split personality is again the source of problems. As members of the public court system, rent-a-judges would best serve society by pronouncing broad rules of wide applicability. As privately hired dispute resolution experts, however, rent-a-judges are more likely to decide cases on very narrow grounds. As Judge Posner and Professor Landes note,

[A] system of voluntary adjudication [such as rent-a-judge] is strongly biased against the creation of precise rules of any sort. Any rule that clearly indicates how a judge is likely to decide a case will assure that no disputes subject to the rule are submitted to that judge since one party will know that it will lose. Judges will tend to promulgate vague standards which give each party to a dispute a fighting chance. ${ }^{181}$

Thus, when shopping for a judge, litigants look for someone who is likely both to rule in their favor and to meet the approval of the opposing party. The ultimate choice will be a judge with a reputation for being impartial, though "impartial" is more likely to mean "accomodating." Rent-a-judges must avoid creating a coherent set of precedents; predictability could destroy a rent-a-judge's appeal to potential customers. In fact, the market provides great incentive for rent-a-judges to be deliberately inconsistent in their

179. Hazard \& Scott, supra note 169 , at 57 .

180. In other words, the litigants, not the judges, "call the shots." They choose the rules and the forum. They rent judges and pay them for their services. Admittedly, this argument is based somewhat on moral indignation at the idea of judges acting less than judgelike and compromising for profit their authority and inherent power as judges. Perhaps, in an economy as service-driven and product-oriented as ours, the idea of state judgments for sale is not so shocking. But then again, perhaps it should be.

181. Landes \& Posner, supra note 165, at 239-40. 
rulings. This behavior by rent-a-judges is destructive in several ways. The body of law thus created is nothing more than a confusing tangle of narrow and contradictory rules, many of which have little relevance to anyone beyond the immediate litigants. ${ }^{182}$ Even if the rules formulated by rent-a-judges are broad enough to be useful to society at large, they are not always likely to reflect the interests of the public. After all, the public is not a paying customer. ${ }^{183}$

\section{Private Judges and the Public Interest}

A rent-a-judge's dual, public-private nature also raises questions about the permissible depth and breadth of a rent-a-judge's decisionmaking authority. Rent-a-judges are chosen by private parties and are not accountable to the public. It is therefore troubling that they should have the authority to impose their rulings upon the whole of society. Rent-a-judges could conceivably address issues involving important civil liberties, such as gun control, school prayer, or abortion. ${ }^{184}$ California statutes allow rent-ajudges to hear any dispute if the parties consent. ${ }^{185}$ Moreover, rent-a-judge judgments are treated exactly the same as other state court judgments and thus presumably have the same effects of collateral estoppel and res judicata. ${ }^{186}$

The public interest, however, demands limits on the reach of rent-a-judge rulings. There are two possible approaches to determining the types of cases suitable for rent-a-judge resolution. One approach would be to categorize cases according to the type of

182. The same argument can be made against binding arbitration. Arbitration, however, is not similarly objectionable because it is a wholly private process. An arbitral award has no impact on the public at large, except tangentially, nor does it affect the body of public law by creating precedent. Rent-a-judge judgments, however, are identical in every respect to public state court judgments. They can be appealed on the merits, and they can be cited. See supra text accompanying notes 30-32. Rent-a-judge judgments, especially if appealed, can thus shape the law and may even have tremendous influence.

183. The same is true of binding arbitration, but again, the product of arbitration is wholly private. The public at large has no interest in arbitral awards because the public does not participate in the process, and arbitral awards create no precedent.

184. Although it is unlikely that the plaintiffs in a case of major constitutional significance would consent to a rent-a-judge, it is not impossible. Moreover, rent-a-judges are already deciding issues of public importance. As mentioned above, rent-a-judges have handled at least two cases involving California state agencies. See stipra notes $62-64$ and accompanying text.

185. Cal. Civ. Proc. Code $\S 638$ (West 1993).

186. Id. $\S 644$ (West Supp. 1994). 
issue at stake; under this approach, disputes over "public law" or "public values," for example, should be reserved for the public courts. ${ }^{187}$ Such cases would include not only those involving constitutional questions or government regulation, ${ }^{188}$ but also those addressing "issues of great public concern," 189 such as the development of legal standards in products liability cases. ${ }^{190} \mathrm{Be}$ cause consent of the litigants is a fundamental element of the renta-judge system, the second approach would focus on the number of people uninvolved in the suit who are likely to be affected by a rent-a-judge judgment. Thus, rent-a-judges would be less suited to render judgments that would otherwise have broad preclusive effects on other potential litigants. ${ }^{191}$ Mass tort cases would be an example. ${ }^{192}$ The two approaches would overlap in some areas; a suit to enjoin discriminatory practices at a factory, for example, would both involve constitutional issues and affect a large number of people uninvolved in the suit. Under either of the preceding approaches, the following types of cases would be particularly suitable for resolution by a rent-a-judge: ${ }^{193}$

187. Harry T. Edwards, Alternative Dispute Resolution: Panacea or Anathema?, 99 HARV. L. REV. 668, 676 (1986).

188. Id. at 671.

189. Id. Arguably, the process of out-of-court settlement also takes "issues of great public concern" away from the courts, and some have argued that this too is undesirable. See Fiss, supra note 168, at 1085 . Settlement negotiations are, however, completely divorced from the official judicial process; rent-a-judging is not. When negotiating for a settlement, lawyers talk dollars more than legal standards, and even if they do discuss legal standards, their discussions have no binding effect on the public at large. Rent-ajudge judgments, on the other hand, have the full force of state court authority. See supra note 31 .

190. Edwards, supra note 187 , at 671.

191. An alternate view that combines these two approaches looks to the "externalities" a case produces, that is, "the effects a transaction or dispute . . . has on those other than the parties themselves." Thomas D. Rowe, Jr., Study on Paths to a "Better Way": Litigation, Alternatives and Accommodation, 1989 DUKE L.J. 824, 868. Cases are less suitable for private resolution if they involve externalities of major concern, such as the development of legal doctrines or the enforcement of important policies. Id.

192. Suppose, for example, that a plane crashes and kills all 300 passengers on board. Suppose, also, that a rent-a-judge resolves the first lawsuit to arise from this accident and holds that the airline was not negligent. The question is whether this judgment should have broad issue-preclusive effect if the survivors of the other 299 passengers were to sue in the same jurisdiction. In light of the concerns discussed above, the answer would seem to be no.

193. This list is by no means exhaustive. Labor disputes, for example, could be well suited for rent-a-judge resolution. 
- Family disputes-Divorces are especially suitable renta-judge cases. Few parties are involved, and the issues at stake are very rarely of public significance.

- Torts-Garden-variety, single-plaintiff cases that require only the application of existing standards are most appropriate for rent-a-judges to hear. ${ }^{194}$ In these cases, the rent-a-judge's function would be mostly factfinding. As discussed above, however, mass tort and products liability cases may be less suited for rent-a-judge courts.

- Complex commercial litigation-Although large sums of money are usually at stake, these cases also involve few interests, and the issues are rarely of significant public importance. Rent-a-judges may even be better suited than public court judges to hear these cases if they have expertise in a particular area.

A number of other types of cases, however, are inappropriate for resolution by rent-a-judges. Many of these have been mentioned above, such as cases involving constitutional questions or government regulation. Agency civil enforcement actions are another example of cases that should stay out of rent-a-judge courts. ${ }^{195}$

Categorizing cases for rent-a-judge resolution is simple in the abstract. But in real life, pure public law cases are harder to spot. ${ }^{196}$ Drafting suitable guidelines for the proper diversion of cases to rent-a-judges would be an extremely difficult task. Enforcement of such guidelines would be even more difficult and could create a whole new area of time-consuming and wasteful litigation. The concerns discussed above cast serious doubt on the utility of rent-a-judges in the public court system. Essentially, the public and private roles of a rent-a-judge cannot be reconciled.

194. Examples include run-of-the-mill negligence cases (such as slip-and-falls), defamation, and trespass.

195. California rent-a-judge courts are already hearing such cases, however. See supra notes $62-64$.

196. As Professor Edwards notes, "[H]idden in many seemingly private disputes are often difficult issues of public law." Edwards, supra note 187, at 671 . 


\section{Efforts at Rent-a-Judge Regulation in California}

The growth of the rent-a-judge industry was largely uncontrolled until last year. In February 1993, the Judicial Council of California adopted a number of new rules to regulate the practice of private judging. The rules came after nearly four years of debate, ${ }^{197}$ and as the product of compromise, they are but a tentative first step toward true regulation of the rent-a-judge business. These rules do nothing to address the larger policy concerns discussed above. They are instead largely cosmetic and attempt to regulate only superficial matters. The rules made three changes: (1) if a party before a rent-a-judge is a "repeat customer," that fact must be disclosed to the other side; (2) rent-a-judge trials must be open to the public; and (3) rent-a-judges may not use public facilities or resources without the consent of the presiding judge. $^{198}$

1. The disclosure requirement. Four new provisions of the California Rules of Court provide, in identical language, as follows:

A privately compensated [temporary judge or referee], as soon as practicable, shall disclose to the parties any potential ground for disqualification ... and any facts that might reasonably cause a party to entertain a doubt that the temporary judge would be able to be impartial. ${ }^{199}$

Although this rule is a good first step toward demanding the ethical conduct of private judges, it leaves a number of concerns unaddressed. Most troubling is the fact that no public or private body exists to discipline rent-a-judges who fail to abide by this rule. ${ }^{200}$ This deficiency presents endless possibilities for conspiracy and fraud.

197. Dresslar, supra note 8, at A5.

198. One superior court judge has pointed out that the promulgators of these rules include many judges who have a vested interest in keeping the rent-a-judge system viable: "[T]he only reason that virtually all sitting judges are in favor of private judging [is because] there is a chance of earning large incomes once they leave the public system. By supporting and working toward this .... institutionalizing [of] private judging, they are feathering their nest." Letter from Judge Robert H. O'Brien, of the California Superior Court, to Andrea L. Biren, Judicial Council of California (July 17, 1992) (on file with the Judicial Council of California) [hereinafter Letter].

199. CAL. R. CT. 244(c), 244.1(b), 532(c), 532.1(b).

200. See Gnaizda, supra note 127, at 12; Vangel, supra note 175 , at 376. 
One proposed solution is to require that rent-a-judges also make their disclosures public. ${ }^{201}$ Indeed, a publicly accessible "track record" of each rent-a-judge's cases can do more to ensure a judge's integrity than reliance on voluntary disclosures. Such a record can also provide more information to prospective customers who would otherwise have to rely on the rent-a-judge's discretion to reveal possible conflicts of interest.

Practically speaking, disclosure may not necessarily have much influence on whom parties choose to be their judge. One of the touted advantages of the rent-a-judge system is the ability of litigants to choose judges with various areas of expertise. If litigants are looking for such an expert, their choices are probably limited.

2. The access requirement. The secrecy of rent-a-judge proceedings has been a primary concern of prior commentators who argued that lack of access violated the First Amendment rights of both the media and the public. ${ }^{202}$ Under the new rules adopted by the Judicial Council, rent-a-judge proceedings must, in theory, be open to the public. $^{203}$ The rules place substantial obstacles, however, to full access.

Most significantly, the new rules do not make rent-a-judge trials routinely accessible. The new rules provide that rent-a-judge trials may "be heard at a site easily accessible to the public and appropriate for seating those who have made known their plan to attend hearings."204 However, such arrangements are required only by order of the presiding judge, either on his own motion or on request "of any person." 205 Moreover, requests for such orders "shall be by letter with reasons stated and shall be accompanied by a declaration that a copy of the request was mailed to each party, to the temporary judge, and to the clerk for placement in the file." 206 A better approach may be to presume that a renta-judge trial is open to the public unless the litigants can give strong reasons to have it closed. ${ }^{207}$ The current rule, with its

201. Letter, supra note 198 , at 7.

202. Perry L. Glantz, Analysis of a First Amendment Challenge to Rent-a-Judge Proceedings, 14 PEPP. L. REv. 989, 1001-02 (1987); see also Christensen, supra note 24, at 93; Vangel, supra note 175, at 388; Note, supra note 100 , at 1608-09.

203. CAL. R. CT. 244(e), 532(e), 244.1(d), 532.1(d).

204. Id. 244(e).

205. Id.

206. Id.

207. Philip Carrizosa, Rent-a-Judge Rule Concerns Media Officials, Los ANGELES DAI- 
many procedural hurdles, may discourage all but the most persistent from attending a rent-a-judge trial.

3. Use of public facilities. Rent-a-judges have had, until recently, free access to public courtrooms and other facilities. Moreover, they have had the power of summoning jurors from the county jury pool. ${ }^{208}$ Although rent-a-judges are nominally adjuncts of the public courts, many people nonetheless have criticized the public financing of what they perceive as wholly private trials. ${ }^{209}$ In response, the Judicial Council has attempted to limit the use of public resources for private trials, and the new rules prohibit the use of public court facilities and the summoning of -jurors "except upon a finding by the presiding judge that the use would further the interests of justice."210

The rules, however, say nothing about exactly what would "further the interests of justice." The rubber-stamping of requests for public services and facilities is a serious concern, especially in light of evidence of back-scratching among public court judges and their rent-a-judge brethren. ${ }^{211}$

These new rules not only are flawed but reveal the Judicial Council's own discomfort and uncertainty over the public-private nature of rent-a-judge proceedings. On the one hand, the access and disclosure requirements seem to imply that rent-a-judges are public officials who must be made accountable. On the other hand, the rule denying rent-a-judges unconditional free access to public facilities implies that rent-a-judges are wholly private figures unsanctioned by the state. The state's confusion over the role of rent-a-judges in the public courts serves as a warning against their widespread use.

LY J., July 28, 1992, at 1 (quoting Bob Rawitch, president of the California First Amendment Coalition).

208. See supra notes $38-46$.

209. See, e.g., REPORT AND RECOMMENDATIONS, supra note 77, at 27-29; Gnaizda, supra note 127, at 12 .

210. CAL. R. CT. 244(d), 532(d), 244.1(c), 532.1(c).

211. REPORT AND RECOMMENDATIONS, supra note 77 , at 39 . The committee heard testimony that several public court judges were pressuring litigants rather heavily to hire rent-a-judges. Id. 


\section{CONCLUSION}

The rent-a-judge system is an unconstitutional, elitist institution that unfairly grants privileges to the wealthy. Moreover, it is the product of a misguided union of the public and private sectors. In private justice, the market is the driving force, and the product is narrow and specialized. In the public courts, broader interests prevail, and the rulings of the public courts govern not only the individual litigants but society at large. The rent-a-judge system is nominally a part of the public courts, but it is essentially marketdriven. Rent-a-judging is the product of a fundamental clash in goals and values, and as such, it cannot and should not survive as a meaningful part of the justice system. 